\title{
O EMPREGO DO GPR NA CARACTERIZAÇÃO DA SUPERFÍCIE E DEPÓSITOS DE FUNDO DA REPRESA GUARAPIRANGA, SÃO PAULO/SP
}

\author{
Renato Hochgreb Frazão \\ Orientador: Dr. Renato Luiz Prado (IAG-USP) \\ 119 p. - Dissertação (Mestrado) - Defesa 08.02.2007
}

\begin{abstract}
RESUMO. 0 reservatório Guarapiranga foi construído entre 1906 e 1909 pela antiga companhia Light Serviços da Eletricidade S/A, destinado à regularização da vazão do rio Tietê e a geração de energia elétrica na Usina Hidrelétrica de Parnaíba no rio Tietê. Atualmente, existe uma preocupação das autoridades públicas com relação à deterioração progressiva da qualidade das águas desse reservatório devido ao aumento da ocupação do solo na região, que vem acarretando uma degradação desse sistema. Essa ocupação vem se desenvolvendo de maneira irregular e clandestina, sem a devida infra-estrutura e em desacordo com o estabelecido na legislação. Isto acarreta num crescente comprometimento da qualidade da água do reservatório devido ao aumento significativo do aporte de nutrientes (principalmente nitrogênio amoniacal e fósforo), além de coliformes fecais através dos tributários ou difusamente ao longo da região ao redor do reservatório. A partir da premissa de que 0 assoreamento pode se constituir num indicador importante como ferramenta de gestão ambiental e que desta forma, há a necessidade, entre outras, de se avaliar periodicamente 0 volume de acumulação e taxa de sedimentação e de lodo, pensou-se num estudo sistemático, dentro de uma área restrita, para avaliar o potencial de emprego do GPR nesta tarefa. Isto significa observar aspectos das suas potencialidades, limitações e acurácia. Este estudo visou o mapeamento da morfologia da superfície de fundo e espessura da camada de lodo depositada no fundo da represa de Guarapiranga. A possibilidade de se obter dados detalhados das características do reservatório de forma indireta (sem a coleta de amostras pontuais) e de forma periódica pode trazer grande auxílio para a proposição de metodologias adequadas à remoção da camada de lodo, com otimização de custos, bem como a proposição de mecanismos de monitoramento e controle do processo de assoreamento e eutrofização da represa. Neste estudo foi escolhido um braço do reservatório associado à micro-bacia do Córrego Guavirutuba, onde as áreas consideradas urbanas e com ocupação precária atingem quase $100 \%$ do total da bacia, portanto, com grande aporte de sedimentos ao reservatório, que se depositam principalmente na desembocadura do mesmo. Os levantamentos GPR foram realizados utilizando-se de antenas de $50 \mathrm{MHz}$ e $100 \mathrm{MHz}$, acopladas em um catamarã de fibra de vidro que por sua vez foi rebocado por um barco de alumínio. Após o processamento e interpretação os resultados foram comparados com os dados de levantamento batimétrico e com 13 furos de sondagens realizadas em pontos coincidentes com o levantamento GPR. Pôde-se, então, verificar a potencialidade e acurácia do método GPR no dimensionamento das espessuras de sedimento. Foram observadas algumas limitações quanto ao alcance das ondas eletromagnéticas em coluna d'água, provavelmente relacionadas à atenuação do sinal devido à condutividade dos materiais, não só na visualização do fundo da represa, como na detecção da espessura da camada de sedimento. Para finalizar, o método GPR mostrou-se eficaz para emprego nas condições dos ensaios realizados. Permitiu a identificação do fundo da represa desde a profundidade de 0,56 $\mathrm{m}$ até 12,47 $\mathrm{m}$ e 0 mapeamento de sedimentos com espessuras de até 6,5 metros (antena de $50 \mathrm{MHz}$ ), mesmo com a condutividade alta da água e a concentração de poluente acima do aceitável para águas de manancial.
\end{abstract}

ABSTRACT. The Guarapiranga reservoir was built between the years of 1906 and 1909 by the former Light Serviços da Eletricidade S/A power company, with the purpose of regulating the water flow from the Tietê river and generating electric energy at Parnaíba Power Plant, located by the same river. The public authorities are currently concerned with the progressive quality deterioration of the water coming from this reservoir, due to the soil occupation increase in that region, causing a degradation of this system. This occupation has been growing in an irregular and illegal way, without the proper infrastructure and in disagreement with what was established by the law. This causes an increasing problem regarding the quality of the water coming from the reservoir, due to the significant increase of nutrient accumulation (mainly ammonia nitrogen and phosphorus), in addition to fecal coliforms through the tributaries or diffusely throughout the region around the reservoir. Considering that the silting can be an important tool for the environmental management, there is the need, among other things, for evaluating periodically the accumulation volume and sedimentation and mud rate, by means of a systematic study, within a restricted area, in order to evaluate the potential use of GPR in this task. This means the observation of its potentialities, limitations and accuracy. This study aimed at the mapping of the morphology of the depth surface and the mud layer thickness deposited at the bottom of the Guarapiranga reservoir. The possibility to obtain indirectly and periodically detailed data from the reservoir (without collecting punctual samples) may help greatly in the proposition of proper methodologies to remove the mud layer, with a cost optimization, as well as in the proposition of utilizing monitoring and control mechanisms of the silting and eutrophication processes in the dam. In this study, an arm of the reservoir associated to the Guavirutuba creek micro-basin was chosen, where areas regarded as urban and with poor occupation comprehend almost $100 \%$ of the total of the basin, therefore, with an intense accumulation of sediments to the reservoir, which is deposited mainly in the mouth of the same. The GPR surveys were performed by using $50 \mathrm{MHz}$ and $100 \mathrm{MHz}$ antennas, coupled to a fiber glass catamaran, which, in its turn, was towed by an aluminum boat. After the processing and interpretation, the results were compared with the batimetric survey data and with 13 boreholes performed in points coinciding with the GPR survey. Therefore, it was possible to verify the potentiality and the accuracy of the GPR method when dimensioning the sediment thicknesses. Some limitations regarding the electromagnetic waves in water columns were observed, probably related to the weakening of the signal due to the conductivity of the materials, not only when visualizing the bottom of the dam, but also when detecting the sediment layer thickness. To conclude, the GPR method turned out to be efficacious to be employed in the conditions of the performed test. It allowed to identify the bottom of the dam, from a depth of $0.56 \mathrm{~m}$ up to $12.47 \mathrm{~m}$ and the mapping of sediments with thicknesses up to 6.5 meters (50 $\mathrm{MHz}$ antenna), even with the high water conductivity and the pollutant concentration above the acceptable regarding fountain waters. 